\title{
ANAS FASCIATA.
}

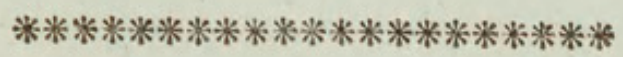

CHARACTER GENERICUS.

Rostrum lamelloso-dentatum, convexum, obtu. sum.

Lingua ciliata, obtusa.

$$
\text { Lin. Syst. Nat. p. } 194 .
$$

CHARACTER SPECIFICUS, Eं.

ANAS albida, fasciis numerosissimis transversis nigris, alis fuscis, occipite subcristato.

Obs. Rostrum pedesque nigra: post oculos utrinque macula elongata rosea: occipitis penne elongate, acuminate, nigra: uropygium albo nigraque fasciatum.

In Australasia generatur nova hæc nec antea descripta species, magnitudine quasi Anatis Querquedulæ Linnæi. 



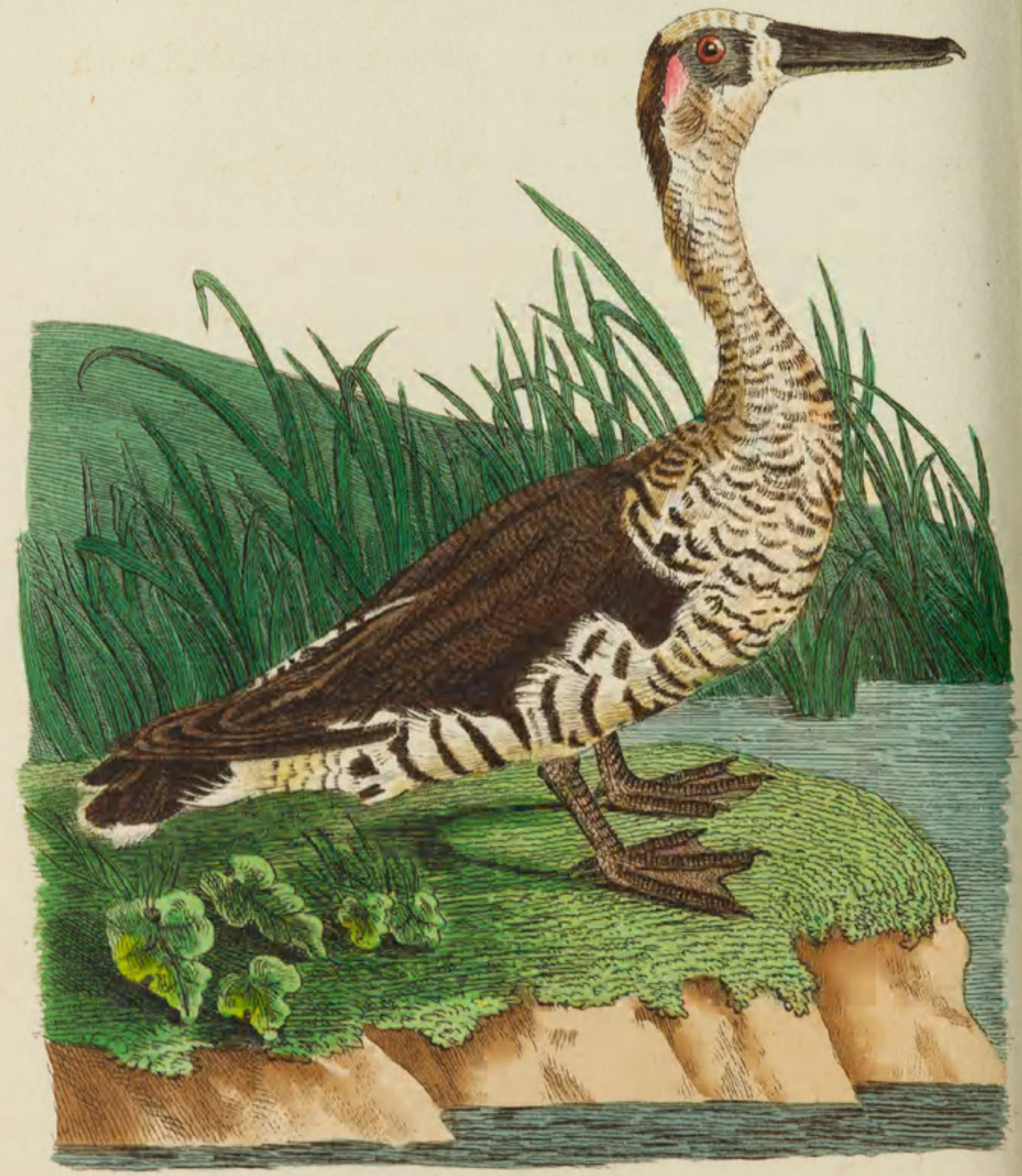

Rrvader-Del t Sulpt 
THE

\section{FASCIATED DUCK.}

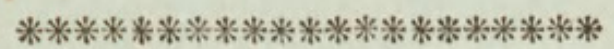

GENERIC CHARACTER.

Bill broad and flattened; the edges marked with sharp lamellæ.

Tongue broad, and ciliated at the edges.

SPECIFIC CHARACTER, छூc.

Whitish DUCK, with very numerous transverse black bands, brown wings, and slightly crested hind-head.

Obs. Bill and legs black: behind the eyes on each side a lengthened rose-coloured spot: feathers of the hind-head lengthened, sharp-pointed, black: rump fasciated with black and white.

The present species which appears to have been hitherto undescribed, is a native of Australasia, and is about the size of the Garganey or Anas Querquedula of Linnæus. 


\section{$2 \mathrm{BHL}$ Biodiversity Heritage Library}

Shaw, George. 1806. "The Fasciated Duck, Anas fasciata [PI. 697]." The Naturalist's Miscellany 17(CCI), https://doi.org/10.5962/p.311134.

View This Item Online: https://www.biodiversitylibrary.org/item/281954

DOI: https://doi.org/10.5962/p.311134

Permalink: https://www.biodiversitylibrary.org/partpdf/311134

\section{Holding Institution}

Museums Victoria

\section{Sponsored by}

Atlas of Living Australia

\section{Copyright \& Reuse}

Copyright Status: Public domain. The BHL considers that this work is no longer under copyright protection.

This document was created from content at the Biodiversity Heritage Library, the world's largest open access digital library for biodiversity literature and archives. Visit BHL at https://www.biodiversitylibrary.org. 